\title{
Breastfeeding indicators in Dakahlia Governorate
}

\author{
A-H. El-Gilany ${ }^{1}$
}

$$
\begin{aligned}
& \text { مؤشِّرات الإرضأع من الثدي في محافظة الدقهلية }
\end{aligned}
$$

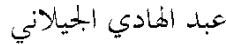

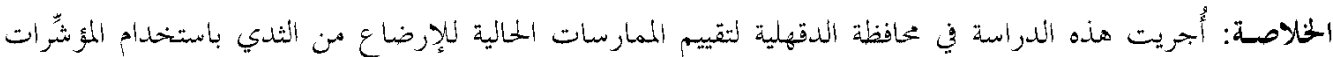

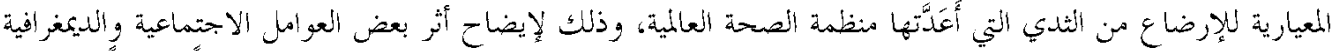

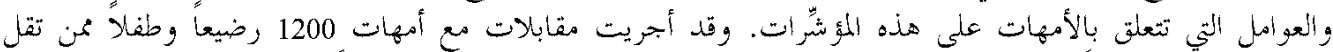

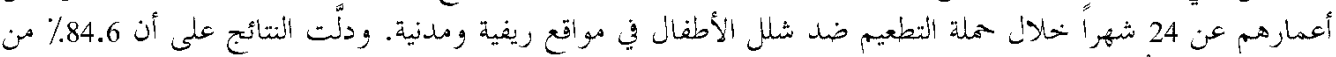

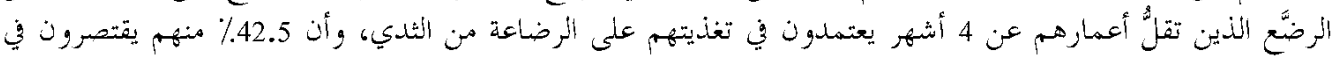

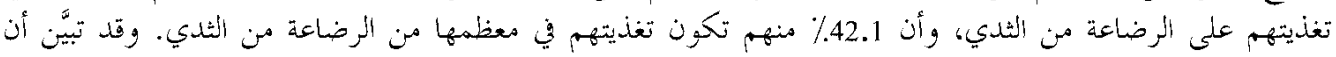

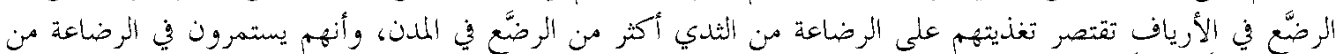

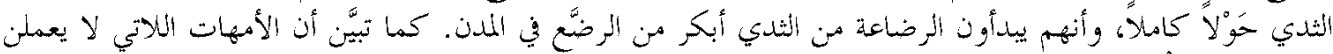

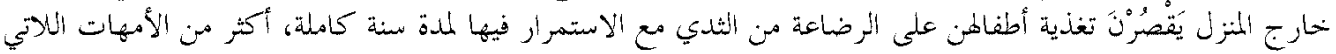

$$
\begin{aligned}
& \text { يعملن خار ج المنزله }
\end{aligned}
$$

ABSTRACT This study was carried out in Dakahlia Governorate to assess current breastfeeding practices using the standardized breastfeeding indicators developed by the World Health Organization and to highlight the impact of some socioeconomic and maternal factors on these indicators. An interview was carried out with mothers of 1200 infants and children $<24$ months during a poliomyelitis immunization campaign in urban and rural areas. The findings indicate that $84.6 \%$ of infants aged $0-4$ months are fully breastfed, with $42.5 \%$ and $42.1 \%$ of them exclusively and predominantly breastfed respectively. Rural infants are more likely to be exclusively breastfed, to continue breastfeeding for 1 year and to initiate breastfeeding early. Non-working mothers are more likely to breastfeed exclusively and more likely to continue breastfeeding for 1 year.

\section{Indicateurs relatifs à l'allaitement au sein dans la Gouvernorat de Dakahlia}

RESUME Cette étude a été réalisée dans le Gouvernorat de Dakahlia afin d'évaluer les pratiques actuelles d'allaitement au sein à l'aide des indicateurs types de l'allaitement au sein établis par l'Organisation mondiale de la Santé et de montrer l'impact de certains facteurs socioéconomiques et maternels sur ces indicateurs. Les mères de 1200 nourrissons et enfants de moins de 24 mois ont été interrogées durant une campagne de vaccination contre la poliomyélitique dans des localités urbaines et rurales. Les résultats indiquent que $84,6 \%$ des nourrissons âgés de $0-4$ mois sont complètement allaités au sein, avec pour $42,5 \%$ et $42,1 \%$ d'entre eux un allaitement maternel exclusif et prédominant, respectivement. Les nourrissons des localités rurales ont plus de chances d'être exclusivement allaités au sein, de continuer à être allaités au sein pendant une année et de commencer à être allaités au sein tôt. Les mères qui ne travaillent pas sont plus susceptibles d'allaiter leur enfant au sein exclusivement et de poursuivre l'allaitement maternel pendant un an.

${ }^{1}$ Department of Community Medicine, Faculty of Medicine, University of Mansoura, Mansoura, Egypt. Received: 26/08/01; accepted: 08/01/02

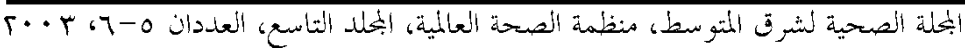




\section{Introduction}

Breastfeeding has been extensively investigated in numerous studies in developing as well as industrialized countries. Egypt is no exception, but the surveys have been conducted in different parts of the country and among special groups using different questionnaires and methodologies and therefore lack uniformity. This has made comparison of the results and assessment of the impact of intervention and promotional programmes most difficult.

The World Health Organization (WHO), United Nations Children's Fund (UNICEF), United States Agency for International Development (USAID) and Swedish International Development Cooperation Agency (SIDA) jointly sponsored a workshop that developed a standardized set of breastfeeding indicators and specific methodologies for their measurements that are simple, easy to measure and operationally feasible. They can be used for national and international comparisons, to monitor secular trends and to assess the impact of intervention [1]. These indicators include:

- Full breastfeeding rate: the proportion of infants less than 4 months of age who are either exclusively breastfed, i.e. without other liquids or solids except for drops or medicinal syrups (exclusive breastfeeding rate) or who are predominantly breastfed, i.e. the infant may also have received water and/or water-based drink (predominant breastfeeding rate).

- Timely complementary feeding rate: the proportion of infants 6-9 months of age who are receiving breast milk plus complementary solid or semi-solid food.

- Continued breastfeeding rate (1 year): the proportion of children 12-15 months of age who are breastfeeding.
- Continued breastfeeding rate (2 year): the proportion of children 20-23 months of age who are breastfeeding.

- Bottle-feeding rate: the proportion of infants less than 12 months who are receiving any food or drink from a bottle.

- Time of first suckling rate: the proportion of infants less than 12 months who first suckled within 1 hour of birth.

- Ever breastfeeding rate: the proportion of infants less than 12 months of age who were ever breastfed.

In this research article the above-mentioned indicators were used to assess breastfeeding practices and to study the influence of different maternal and socioeconomic factors on them.

\section{Methods}

This work was carried out in both urban and rural areas of Dakahlia governorate. From urban localities, Mansoura and Sherbin Health Offices were randomly chosen. From rural localities, 4 rural heath units were randomly chosen from the villages of Nikata, Ewish El-Hagar, Kafr ElShenawie and El-Ahmadia. These belong to Mansoura and Sherbin districts.

The target population was children below 2 years of age and their mothers. During the first and second doses of a poliomyelitis vaccination campaign, the researcher carried out an exit interview with the mothers and completed a structured questionnaire covering family socioeconomic status and maternal characteristics as well as feeding practices during the previous 24 hours. The social standard of the family was calculated according to Fahmy and El-Sherbini [2]. For 10 mother-child pairs in each completed month, up to the age of 12 months, as well as in the age 
groups of 12-15 months and 20-23 months, the mother was interviewed in each health facility. The mother-child pairs were randomly chosen through systematic random sample. Thus a total of 1200 mother-child pairs were included in the study (60 in each target month of age). The breastfeeding indicators were based on the current status data, i.e. the age and other information for the 24 hours preceding the interview as recommended by WHO [1]. Age was ascertained by reviewing the birth certificate, which was available in the majority of cases.

\section{Data analysis}

Data entry, processing and statistical analysis were carried out using SPSS, version 9.5. Because exclusive and predominant breastfeeding rates are mutually exclusive, further analysis was restricted to exclusive breastfeeding rate. Chi-squared and Fisher exact tests of significance were used to compare different groups, as appropriate. $P \leq 0.05$ was considered to be statistically significant.

Because many co-factors affecting breastfeeding practices are interrelated, logistic regression analysis was undertaken to gain insight into factors associated with this practice. Factors that were found to be significant on univariate analysis were included in the logistic regression model.

\section{Results}

Table 1 shows breastfeeding rates in Dakahlia governorate. Exclusive and predominant breastfeeding rates were $42.5 \%$ and 42.1\% respectively. As these 2 rates are mutually exclusive, $84.6 \%$ of infants were currently fully breastfed at the time of the interview. The timely complementary feeding rate was $44.2 \%$. The continued breast- feeding rates at 1 and 2 years of age were $67.9 \%$ and $58.8 \%$ respectively. The bottlefeeding rate was $35.7 \%$. The time of first suckling rate was $28.5 \%$ and the ever breastfeeding rate was $92.9 \%$. The causes of never breastfeeding among infants less 12 months of age were: no or insufficient milk (51.0\%), breast or nipple problems (27.5\%), infant refusing to suck (15.7\%), infant's illness (9.8\%) and maternal illness (9.8\%).

Table 2 reveals that the exclusive breastfeeding rate was significantly higher among infants of rural residence, nonworking mothers, less educated mothers, those having low social standards and short interpregnancy interval. The timely complementary feeding rate was significantly higher among infants of urban residence, working mothers, more educated mothers, those of high or middle social standards and short interpregnancy interval.

Table 3 reveals that the continued breastfeeding rate at 1 year was significantly higher among rural children, children of non-working mothers, those of less educated mothers, low social standards, second and third parity, long interpregnancy interval and male infants. The continued breastfeeding rate at 2 years was significantly higher among rural children, children of non-working mothers, those of less educated mothers, low social standards, older age groups and long interpregnancy interval.

Table 4 shows that the bottle-feeding rate was significantly higher among urban infants, those of working mothers, more educated mothers, high social standards, younger age groups, primipara and fourth para or more and long interpregnancy interval. The ever breastfeeding rate was significantly higher among rural infants, those of less educated mothers, low social stan-

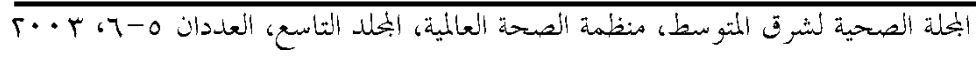




\begin{tabular}{lcccc}
\hline $\begin{array}{l}\text { Table 1 Breastfeeding (BF) indicators among the infants and } \\
\text { children in Dakahlia Governorate }\end{array}$ & & & \\
\hline Indicator & $\begin{array}{c}\text { Related age } \\
\text { (months) }\end{array}$ & $\begin{array}{c}\text { Total } \\
\text { children }\end{array}$ & $\begin{array}{c}\text { Rate } \\
\text { No. }\end{array}$ & $\%$ \\
\hline Key indicators & & & & \\
Full BF rate & $<4$ & $240^{\mathrm{a}}$ & $203 / 240$ & 84.6 \\
Exclusive BF rate & - & - & $102 / 240$ & 42.5 \\
Predominant BF rate & - & - & $101 / 240$ & 42.1 \\
Timely complementary & & & & \\
feeding rate & $6-9$ & 240 & $106 / 240$ & 44.2 \\
$\quad$ Continued BF rate (1 year) & $12-15$ & 240 & $163 / 240$ & 67.9 \\
$\quad$ Continued BF rate (2 years) & $20-23$ & 240 & $141 / 240$ & 58.8 \\
Bottle-feeding rate & $<12$ & 720 & $257 / 720$ & 35.7 \\
$\begin{array}{l}\text { Optional additional indicators } \\
\text { Time of first suckling rate }\end{array}$ & $<12$ & 720 & $205 / 720$ & 28.5 \\
Ever BF rate & $<12$ & 720 & $669 / 720$ & 92.9 \\
\hline
\end{tabular}

a16 (6.7\%) infants were never breastfed and 21 (8.8\%) infants were given non-human milk in addition to breastfeeding.

dards, as well as mothers of second and third para. The time of first suckling rate was significantly higher among rural infants, those of more educated mothers, low social standards and long interpregnancy interval.

Table 5 reveals that rural infants are 3.5 times more likely to breastfeed exclusively and 0.2 times less likely to receive timely complementary feeding than urban infants. Infants of non-working mothers are 11.5 times more likely to breastfeed exclusively than those of working mothers. On the other hand, mothers with short interpregnancy interval are 0.08 times less likely to breastfeed their infants exclusively. Mothers with short interpregnancy interval are about 7 times more likely to give timely complementary feeds to their infants than those with long interval. Rural infants and children of non-working mothers are 5.8 and 5.0 times more likely to continue breastfeeding for 1 year, respectively. Children of mothers with short interpregnancy interval are 0.04 times less likely to continue breast- feeding up to one year. Children of less educated mothers and those of mothers with low socioeconomic status are 9.8 and 6.0 times more likely to breastfeed up to 2 years, respectively. On the other hand, children of mothers with short inter-pregnancy interval are 0.01 times less likely to continue breastfeeding for 2 years. Bottle-feeding is less likely to be practised by rural infants, those of less educated mothers, of low and middle social status, of middle aged mothers and of mothers of parity 2 or 3. Rural infants are 3.7 times more likely to initiate breastfeeding early than urban infants, while infants of less educated mothers and those of mothers with short inter-pregnancy space are 0.3 and 0.4 (respectively) less likely to initiate breastfeeding early.

\section{Discussion}

The superiority of breastfeeding is unchallenged. Its benefits to both child and mother have been widely documented $[3,4]$. The 


\begin{tabular}{|c|c|c|c|c|c|c|}
\hline \multicolumn{7}{|c|}{ Eastern Mediterranean Health Journal, Vol. 9, Nos 5/6, 2003} \\
\hline \multicolumn{7}{|c|}{$\begin{array}{l}\text { Table } 2 \text { Factors affecting exclusive breastfeeding and timely complementary } \\
\text { feeding rates }\end{array}$} \\
\hline \multirow[t]{2}{*}{ Variable } & \multicolumn{3}{|c|}{$\begin{array}{l}\text { Exclusive breastfeeding } \\
\text { rate (1-4 months) }\end{array}$} & \multicolumn{3}{|c|}{$\begin{array}{l}\text { Timely complementary feeding } \\
\text { rate (6-9 months) }\end{array}$} \\
\hline & Total & No. & $\%$ & Total & No. & $\%$ \\
\hline \multicolumn{7}{|l|}{ Residence } \\
\hline Rural & 160 & 81 & $50.9^{\star \star \star}$ & 160 & 58 & $36.3^{\star \star \star}$ \\
\hline Urban & 80 & 21 & 26.3 & 80 & 48 & 60.0 \\
\hline \multicolumn{7}{|l|}{ Mother working } \\
\hline Yes & 152 & 83 & $54.6^{\star \star \star}$ & 157 & 60 & $38.2^{*}$ \\
\hline No & 88 & 19 & 21.6 & 83 & 46 & 55.4 \\
\hline \multicolumn{7}{|l|}{ Mother's education } \\
\hline Less than secondary & 145 & 69 & $47.6^{\star}$ & 155 & 58 & $37.4^{* *}$ \\
\hline Secondary and above & 95 & 33 & 34.7 & 85 & 48 & 56.5 \\
\hline \multicolumn{7}{|l|}{ Social standard } \\
\hline Low & 112 & 59 & $52.7^{\star \star}$ & 147 & 50 & $34.0^{\star * \star}$ \\
\hline Middle & 92 & 33 & 35.9 & 64 & 39 & 60.9 \\
\hline High & 36 & 10 & 27.8 & 29 & 17 & 58.6 \\
\hline \multicolumn{7}{|l|}{ Mother's age (years) } \\
\hline$<20$ & 28 & 9 & 32.1 & 32 & 10 & 31.3 \\
\hline $20-35$ & 155 & 69 & 44.5 & 158 & 70 & 44.3 \\
\hline$>35$ & 57 & 24 & 42.1 & 50 & 26 & 52.0 \\
\hline \multicolumn{7}{|l|}{ Parity } \\
\hline Primipara & 56 & 17 & 30.4 & 49 & 21 & 42.9 \\
\hline 2 and 3 & 115 & 54 & 47.0 & 103 & 40 & 38.8 \\
\hline 4 and more & 69 & 31 & 44.9 & 88 & 45 & 51.1 \\
\hline \multicolumn{7}{|l|}{$\begin{array}{l}\text { Interpregnancy } \\
\text { intervala (years) }^{2}\end{array}$} \\
\hline$<3$ & 113 & 44 & $38.9^{\star \star \star}$ & 111 & 64 & $57.7^{\star \star *}$ \\
\hline 3 & 64 & 41 & 64.1 & 80 & 21 & 26.3 \\
\hline \multicolumn{7}{|l|}{ Sex of infant } \\
\hline Female & 116 & 48 & 41.1 & 110 & 47 & 42.7 \\
\hline Male & 124 & 54 & 43.5 & 130 & 59 & 45.4 \\
\hline
\end{tabular}

aPrimiparae were excluded.

*Significant at $\mathrm{P} \leq 0.05,{ }^{* *}$ significant at $\mathrm{P} \leq 0.01,{ }^{* *}$ significant at $\mathrm{P} \leq 0.001$.

Egyptian government has adopted a national policy in line with the WHO/UNICEF policy for protection, promotion and support of breastfeeding.

In this study, we found that the majority (84.6\%) of infants less than 4 months of age were on full breastfeeding, either ex- 


\begin{tabular}{|c|c|c|c|c|c|c|}
\hline \multirow[t]{2}{*}{ Variable } & \multicolumn{3}{|c|}{$\begin{array}{l}\text { Continued breastfeeding rate } \\
\text { (1 year) (12-15 months) }\end{array}$} & \multicolumn{3}{|c|}{$\begin{array}{l}\text { Continued breastfeeding rate } \\
\text { (2 years) (20-23 months) }\end{array}$} \\
\hline & Total & No. & $\%$ & Total & No. & $\%$ \\
\hline \multicolumn{7}{|l|}{ Residence } \\
\hline Rural & 160 & 120 & $75.0^{\star \star \star}$ & 160 & 103 & $64.4^{\star \star}$ \\
\hline Urban & 80 & 43 & 53.8 & 80 & 37 & 46.3 \\
\hline \multicolumn{7}{|l|}{ Mother working } \\
\hline No & 156 & 123 & $78.8^{\star \star \star}$ & 158 & 102 & $64.6^{*}$ \\
\hline Yes & 84 & 40 & 47.6 & 82 & 39 & 47.6 \\
\hline \multicolumn{7}{|l|}{ Mother's education } \\
\hline Less than secondary & 152 & 112 & $73.7^{*}$ & 141 & 92 & $65.2^{*}$ \\
\hline Secondary \& above & 88 & 51 & 58.0 & 99 & 49 & 49.5 \\
\hline \multicolumn{7}{|l|}{ Social standard } \\
\hline Low & 99 & 79 & $79.8^{\star \star}$ & 100 & 71 & $71.0^{\star \star \star}$ \\
\hline Middle & 81 & 52 & 64.2 & 76 & 43 & 56.6 \\
\hline High & 60 & 32 & 19.6 & 64 & 27 & 42.2 \\
\hline \multicolumn{7}{|l|}{ Mother's age (years) } \\
\hline$<20$ & 30 & 17 & 56.7 & 35 & 12 & $34.3^{\star *}$ \\
\hline $20-35$ & 148 & 107 & 72.3 & 144 & 89 & 61.8 \\
\hline$>35$ & 62 & 39 & 62.9 & 61 & 40 & 65.6 \\
\hline \multicolumn{7}{|l|}{ Parity } \\
\hline Primipara & 51 & 29 & $56.9^{*}$ & 69 & 37 & 53.6 \\
\hline 2 and 3 & 116 & 88 & 75.9 & 91 & 58 & 63.7 \\
\hline 4 and more & 73 & 46 & 63.0 & 80 & 46 & 57.5 \\
\hline \multicolumn{7}{|l|}{ Interpregnancy interva/ ${ }^{a}$} \\
\hline$<3$ years & 98 & 58 & $59.2^{\star \star \star}$ & 95 & 50 & $52.6^{\star}$ \\
\hline 3 years or more & 91 & 76 & 83.5 & 76 & 54 & 71.1 \\
\hline \multicolumn{7}{|l|}{ Sex of infant } \\
\hline Female & 110 & 66 & $60.0^{*}$ & 114 & 62 & 54.4 \\
\hline Male & 130 & 97 & 74.6 & 126 & 79 & 62.7 \\
\hline
\end{tabular}

aPrimiparae were excluded.

*Significant at $\mathrm{P} \leq 0.05,{ }^{* *}$ significant at $\mathrm{P} \leq 0.01,{ }^{* * *}$ significant at $\mathrm{P} \leq 0.001$.

Egypt has been reported as $63.3 \%$ among infants less than 4 months of age [8]. A much lower rate of full breastfeeding (41.8\%) has been reported for the Republic of Yemen [9]. In rural Thailand, the proportions of infants who were fully breastfed for at least 12 and 24 weeks were $12 \%$ and $6 \%$ respectively [10].
In Indonesia, the full breastfeeding rate at 3 months ranged from $45 \%$ to $79 \%$ in different urban areas [11]. The present study indicates that only $42.5 \%$ of the infants were on exclusive breastfeeding in Dakahlia. This rate is much lower than the $80 \%$ target set for the year 2000 [12]. A higher rate $(57.8 \%)$ was found in rural Da- 


\begin{tabular}{|c|c|c|c|c|c|c|c|}
\hline \multicolumn{8}{|c|}{$\begin{array}{l}\text { Table } 4 \text { Factors affecting bottle-feeding, ever breastfeeding and time of first suckling } \\
\text { rates }\end{array}$} \\
\hline \multirow[t]{2}{*}{ Factor (1-12M) } & \multirow[b]{2}{*}{ Total } & \multicolumn{2}{|c|}{$\begin{array}{l}\text { Bottle-feeding } \\
\text { rate }\end{array}$} & \multicolumn{2}{|c|}{$\begin{array}{l}\text { Ever breastfeeding } \\
\text { rate }\end{array}$} & \multicolumn{2}{|c|}{$\begin{array}{l}\text { Time of first } \\
\text { suckling rate }\end{array}$} \\
\hline & & No. & $\%$ & No. & $\%$ & No. & $\%$ \\
\hline \multicolumn{8}{|l|}{ Residence } \\
\hline Rural & 480 & 119 & $24.8^{\star \star \star}$ & 456 & $95.0^{\star \star}$ & 160 & $33.3^{\star * \star}$ \\
\hline Urban & 240 & 138 & 57.5 & 213 & 88.8 & 45 & 18.8 \\
\hline \multicolumn{8}{|l|}{ Mother's education } \\
\hline Less than secondary & 458 & 122 & $26.6^{\star \star *}$ & 434 & $94.8^{*}$ & 110 & $24.0^{\star \star \star *}$ \\
\hline Secondary \& above & 262 & 135 & 51.5 & 235 & 89.7 & 95 & 36.3 \\
\hline \multicolumn{8}{|l|}{ Social standard } \\
\hline Low & 383 & 96 & $25.1^{\star \star \star}$ & 364 & $95.0^{\star \star}$ & 95 & $24.8^{*}$ \\
\hline Middle & 226 & 88 & 38.9 & 210 & 92.9 & 79 & 35.0 \\
\hline High & 111 & 73 & 65.8 & 95 & 85.6 & 31 & 27.9 \\
\hline \multicolumn{8}{|l|}{ Mother's age (years) } \\
\hline$<20$ & 85 & 42 & $49.4^{\star \star \star}$ & 76 & 89.4 & 28 & 32.9 \\
\hline $20-35$ & 471 & 144 & 30.6 & 444 & 94.3 & 132 & 28.0 \\
\hline$>35$ & 164 & 71 & 43.3 & 149 & 90.9 & 45 & 27.4 \\
\hline \multicolumn{8}{|l|}{ Parity } \\
\hline Primipara & 149 & 64 & $43.0^{\star \star \star}$ & 133 & $89.3^{*}$ & 34 & 22.4 \\
\hline 2 and 3 & 365 & 100 & 27.4 & 347 & 95.1 & 107 & 29.3 \\
\hline 4 and more & 206 & 93 & 45.1 & 189 & 91.7 & 64 & 31.1 \\
\hline \multicolumn{8}{|l|}{ Interpregnancy intervala } \\
\hline$<3$ years & 308 & 89 & $28.9^{\star \star}$ & 291 & 94.5 & 63 & $20.5^{\star \star \star}$ \\
\hline 3 years or more & 263 & 104 & 39.5 & 245 & 93.2 & 108 & 41.1 \\
\hline \multicolumn{8}{|l|}{ Sex of infant } \\
\hline Female & 319 & 121 & 37.9 & 294 & 92.2 & 86 & 27.0 \\
\hline Male & 401 & 136 & 33.9 & 375 & 93.5 & 119 & 29.7 \\
\hline
\end{tabular}

a Primiparae were excluded.

*Significant at $\mathrm{P} \leq 0.05,{ }^{* *}$ significant at $\mathrm{P} \leq 0.01$, ***significant at $\mathrm{P} \leq 0.001$.

kahlia [5]. The reported rate in Alexandria was $42.2 \%$. The Egypt Demographic and Health Survey (EDHS) 1995 reported that the overall Egypt exclusive breastfeeding rate was $24.1 \%$ at $4-6$ months of age [7]. An exclusive breastfeeding rate of $49.0 \%$ was reported for Assiut and Qena, Egypt [13]. The exclusive breastfeeding rate among infants less than one year of age was $37.0 \%$ and $22.5 \%$ in rural Minia and $32.3 \%$ and $12.5 \%$ in Cairo slums [14]. In the Republic of Yemen, the exclusive breastfeeding rate was reported to be $39.8 \%$ among infants less than 4 months age [9]. In Saudi Arabia, 50\% of infants were exclusively breastfed at 3 months of age [15]. It was found that $46.3 \%$ of infants received decoctions before the age of 4 months [16]. Some studies therefore stated that exclusive breastfeeding, taken in its literal meaning according to the $\mathrm{WHO} /$ UNICEF definition, does not seem to exist

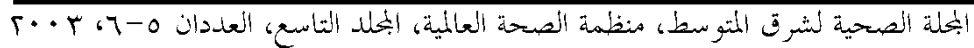




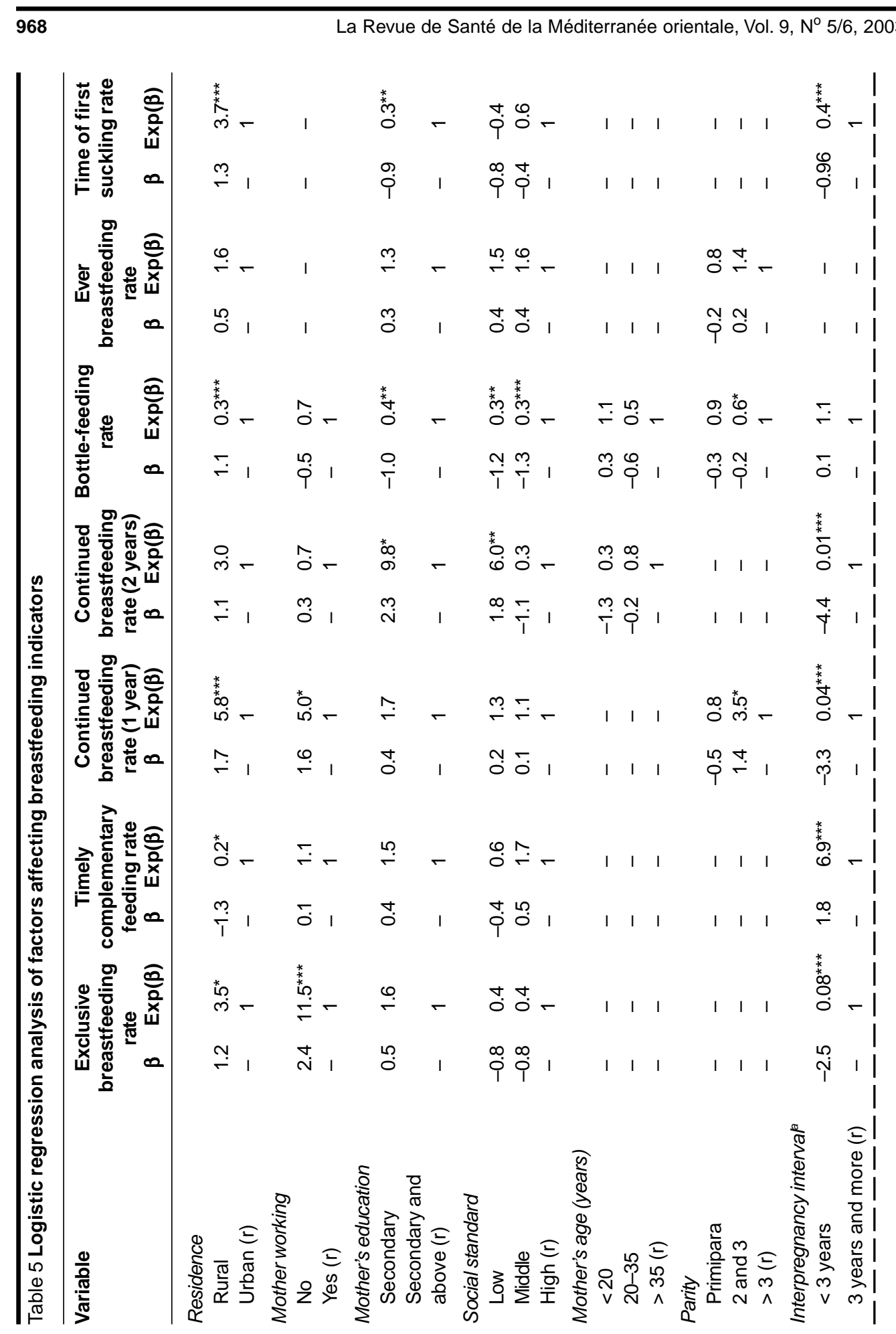

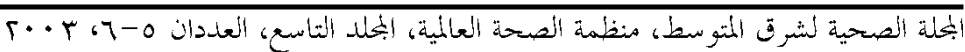


in Egypt, especially as health workers consider some decoctions necessary.

It has been recommended that no food or drink be given to infants before complementary feeding is required at 4 to 6 months $[3,16]$. In the present work, $42.1 \%$ of infants less than 4 months of age were predominantly breastfed. This rate is higher than that reported for rural Dakahlia (37.1\%) [5], Alexandria (24.1\%) [8], Qena and Assiut (40.0\%) [13] and overall Egypt (33.0\%) [6]. However, UNICEF reported a higher rate of $56.1 \%$ for Egypt [15]. A much lower rate (2.0\%) was reported for the Republic of Yemen.

Inadequate quantity or quality of complementary foods causes growth failure in developing countries [17]. The timely complementary feeding rate reported in this study is $44.2 \%$. This rate is higher than the rate of $34.5 \%$ in rural Dakahlia [5], the rate of $35.7 \%$ reported by UNICEF for Egypt [15], as well as the rate of $27.3 \%$ and $31.3 \%$ reported for Aswan and Assiut respectively [18]. However, higher rates have been reported for Alexandria (62.3\%) [8]; Dakahlia and North Sinai $(46.7 \%$ and $54.2 \%$ respectively) [18]; and Qena and Assiut (49.0\%) [13] by the EDHS in 1995 (77.0\% among infants of 7-9 months of age) [7] as well as for the Republic of Yemen (57.4\%) [9].

In the present study the continued breastfeeding rates at 1 and 2 years were $67.9 \%$ and $58.8 \%$ respectively. These rates are lower than the $96.1 \%$ and $89.9 \%$ reported for rural Dakahlia [5]. The corresponding rates were 64.4\% and 33.9\% for Alexandria [8], $80.8 \%$ and $49.0 \%$ for Assiut and Qena [13] and $60.9 \%$ and $36.4 \%$ for the Republic of Yemen [9]. EDHS 1995 reported that at 12-13 months of age,

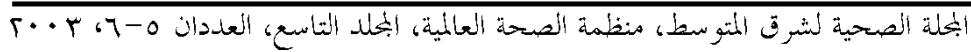


$79 \%$ of children are still being breastfed and more than half of children aged 18-19 months continue to be breastfed [7]. In Dakahlia, $20.0 \%$ and $53.3 \%$ of mothers stopped breastfeeding at $12-18$ months and 18-24 months respectively [18]. Dandash et al. reported that only $20.4 \%$ and $4.6 \%$ of mothers breastfed their babies for more than 12 and 24 months respectively [19].

Mothers should be encouraged to use a cup and spoon for feeding rather than bottles because of the interference of bottles with optimal breastfeeding practices $[6,8]$. This study revealed that the bottle-feeding rate among infants less than 1 year was $35.7 \%$. This is higher than the rate of $27 \%$ reported for rural Dakahlia [5], the rate of 25.6\% reported by UNICEF for Egypt [15] and $25.1 \%$ for the Republic of Yemen [9]. EDHS 1992 reported that nearly one-fifth of breastfed infants less than 8 months of age were given the bottle with nipple [6]. However, higher bottle-feeding rates were reported by Kamel et al. for Alexandria (44.3\%) [8] and by the Egyptian Maternal and Child Health Survey (EMCHS) for urban governorates (42\%) [20].

Early suckling enhances lactation and encourages the psychological bonding between mother and baby [21]. In many countries there is a delay in initiation of breastfeeding until the second or third day after birth [22]. The present work revealed that $28.5 \%$ of infants less than 12 months of age started breastfeeding within an hour of birth. EDHS 1995 reported that 40\% of children who were ever breastfed were put to the breast within an hour of delivery [7]. In the Republic of Yemen, none of the infants less than 12 months of age started suckling within the first hour of birth [9]. UNICEF in Egypt reported that in normal deliveries, $20.3 \%$ and $35.3 \%$ of infants breastfeed within one half and 1-2 hours of birth respectively [15]. In Dakahlia, 69.7\% of infants started breastfeeding within 2 hours of birth [23]. Saker reported that 82\% of Egyptian women believe that the best time for starting breastfeeding is on the third day after delivery [24]. Avoidance of breastfeeding in the first three days of birth was practised in Aswan (59.4\%), Assiut (57.7\%) and Dakahlia (56.2\%) [25]. In many countries, it is believed that colostrum is unfit for the newborn. Therefore, mothers express it and throw it away until the "true" milk appears on the third day after birth [26].

In this work, the ever breastfeeding rate was $92.9 \%$ among infants less than 12 months of age. This means that $7.1 \%$ of the infants were never breastfed. This figure is comparable to the $5.7 \%$ to $7.3 \%$ rates reported for Dakahlia [5,23,27]. The frequency of never breastfeeding was $2.5 \%$ in rural Thailand [10], 6\%-19\% in Indonesia [11] and 7\%-11\% in the Philippines [28]. The causes of never breastfeeding were comparable to those reported from other studies [5,27,28,29].

The impact of different factors on breastfeeding indicators was studied. Factors found to have a significant effect on univariate analysis were entered into multivariate analysis. By logistic regression, it was found that rural mothers are 3.5 times more likely to breastfeed exclusively, 5.8 times more likely to continue breastfeeding for 1 year and 3.7 times more likely to start breastfeeding within one hour of delivery than urban mothers. On the other hand, they are 0.2 times less likely to give timely complementary feeding than urban mothers.

This study revealed that maternal work outside the home has a profound impact on the exclusive breastfeeding rate and the continued breastfeeding rate for 1 year. Non-working mothers are 11.5 times more likely to breastfeed exclusively and 5.0 
times more likely to continue breastfeeding for 1 year. A meta-analysis of 30 Egyptian studies showed that working mothers tend to shift earlier than non-working mothers from exclusive breastfeeding to mixed (breast and formula) feeding. Earlier termination of breastfeeding was also more common among working mothers. This suggests that maternal work is not the key determinant of infant feeding practices, and that the local and temporal norms may be the main factors determining infant feeding practices. The reasons for successful breastfeeding are thought to be influenced by psychological, social and economic factors [19,30,31]. El-Masry reported that maternal work has insignificant effect on ever breastfeeding and continued breastfeeding for 1 and 2 years [32]. However, the exclusive breastfeeding rate was significantly lower, while the timely complementary feeding and bottle-feeding rates were significantly higher among working than non-working mothers. In Egypt, all working mothers receive only 3 months fully paid maternal leave [19].

Less-educated mothers are 9.8 times more likely to continue breastfeeding for 1 year, 0.4 times less likely to use bottlefeeding and 0.3 times less likely to start breastfeeding at the proper time.

Mothers of low socioeconomic standard are 6 times more likely to continue breastfeeding for 2 years than those of high socioeconomic standard. Also, mothers of low and middle standard are 0.3 times less likely to use the bottle for infant feeding than those of high standard. Mothers aged 20-35 years and those with 2 and 3 children are 0.3 times less likely to use bottle- feeding than older mothers and mothers with higher parity. Mothers of 2 and 3 para are 3.5 times more likely to continue breastfeeding for 1 year than mothers with higher parity. Early initiation of breastfeeding has been reported to be significantly more common among older mothers and mothers with 2 and 3 para [23].

Short interpregnancy interval has a negative impact on most of the breastfeeding indicators. Mothers with short spacing (interval less than 3 years) are 0.08 times less likely to breastfeed exclusively up to the age of 4 months, 0.04 and 0.01 times less likely to continue breastfeeding for 1 and 2 years, and 0.4 times less likely to start breastfeeding early than mothers with adequate birth spacing. On the other hand, non-spacers are about 7 times more likely to introduce complementary feeding at 6-9 months of age.

To promote breastfeeding in our society, it is recommended that efforts be directed towards the appropriate target groups, such as working mothers, urban mothers, non-spacers and more educated mothers. Religious quotations that favour and emphasize the importance of providing breast milk to infants should be used in education campaigns to counteract the incorrect beliefs that interfere with breastfeeding. The Quranic prescription to breastfeed for 2 years has been found to be greatly honoured by the majority of mothers [18]. Family planning with adequate pregnancy spacing will also have a positive impact on breastfeeding practices. Finally, work legislation that extends the duration of fully paid maternity leave needs to be considered.

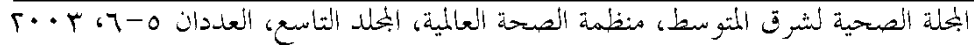




\section{References}

1. Indicators for assessing breast-feeding practices: report of an informal meeting, 11-12 June 1991, Geneva, Switzerland. Geneva, World Health Organization, 1991:14.

2. Fahmy SI, El-Sherbini AF. Determining simple parameters for social classifications for health research. Bulletin of the High Institute of Public Health, 1983, 13(5):95-108.

3. Breastfeeding practice. Facts for action for health professionals. Baby and Mother Friendly Hospital Initiative. Cairo, Egypt, Ministry of Health and Population, 1993.

4. Breastfeeding and the use of human milk. American Academy of Pediatrics. Work Group on Breastfeeding. Pediatrics, 1997, 6:1035-39.

5. Al-Gilany A, Settin AS. Standardized indicators of breast-feeding in rural Dakahlia, Egypt: possible influencing maternal and sociobiological factors. Egyptian journal of paediatrics, 1997, 14(1\&2):117-28.

6. Egyptian Demographic and Health Survey 1992. Cairo, National Population Council and Maryland, Macro International Incorporated, 1993.

7. Egyptian Demographic and Health Survey 1995. Cairo, National Population Council and Maryland, Macro International Incorporated, 1996.

8. Kamel NM et al. Current status of breastfeeding in Alexandria governorate: a community-based study. Eastern Mediterranean health journal, 1997, 3(3):511-18.

9. Abuluhum TS et al. Breastfeeding practice in Dammar, Republic of Yemen [Letter to the Editor]. Middle East paediatrics, 1999, 4(1):11-13.
10. Kamnuansilpa P, Knodel J. Mortality, health and infant feeding practices in the Northeast of Thailand. Methodological issues and substantive results. Bangkok, National Institute of Development Administration, 1985.

11. Hull VJ et al. Breast-feeding and health professionals: a study in hospitals in Indonesia. Social science \& medicine, 1989, 28(4):355-64.

12. National achievements and challenges. Mid-decade goals, Cairo, Egypt, Ministry of Local Administration and United Nations Children's Fund, 1996.

13. Combined Control of Diarrheal Diseases and Acute Respiratory Infections Household Survey (CCDD/ARI). Cairo, Egypt, Ministry of Health and Population, 1996.

14. Hegazy IS et al. Maternal health profile. A comparative study between rural Minia and Cairo slums 1997. Egyptian journal of community medicine, 1999, 17(1):5765.

15. Pre- and post-implementation. Multicenter Baby Friendly Hospital Initiative (BFHI) studies in Egypt, Cairo, Egypt, United Nations Children's Fund, 1993.

16. Feachem RG, Koblinsky MA. Interventions for the control of diarrhoeal diseases among young children: promotion of breastfeeding. Bulletin of the World Health Organization, 1984, 62(2):27191.

17. Rivera J, Martorel LR. Nutrition, infection and growth. Part I. Effects of infection on growth. Clinical nutrition, 1998, 7:15662.

18. Hassanyn SAM. Complementary feeding and weaning practices in four governorates in Egypt. Eastern Mediterranean health journal. 1998, 4(1):173-7. 
19. Dandash BK et al. Factors associated with duration of breast-feeding practice. Egyptian journal of community medicine, 1993, 11(1):19-26.

20. Abdel-Azeem F et al. Breast-feeding and weaning practices. Egyptian Maternal and Child Health Survey (EMCHS) 1991, Cairo, Egypt, Pan Arab Project for Child Development, League of Arab States, 1991.

21. Labbok MH, Krasovec K, eds. Guidelines for breast-feeding in child survival and family programs. Washington DC, Georgetown University, International Studies in Natural Family Planning, 1989.

22. Green CP. Media promotion of breastfeeding. A decade experience. Washington DC, Academy for Educational Development, 1989:33.

23. Abdel-Wahab $\mathrm{F}$ et al. Factors affecting breast-feeding initiation. Egyptian journal of community medicine, 1993, 11(1): 9-17.

24. Saker E. KAP. Study in rural Egypt about breastfeeding. Fertility care bulletin, 1984, 22-23:9.

25. Hassanyn SA. Beliefs and practices associated with breast-feeding. Bulletin of the Nutrition Institute, 1995, 15(1):1-6.

26. Fishman $\mathrm{C}$ et al. Warm bodies, cool milk: conflicts in post-partum food choice for
Indochinese women in California. Social science \& medicine, 1988, 26:1125-32.

27. Khafagy MN. Study on breastfeeding [MSc Thesis in Public Health]. Mansoura, Egypt, Faculty of Medicine, University of Mansoura, 1990.

28. Williamson NE. Breast-feeding trends and the breast-feeding program in the Philippines. International journal of gynaeco-logy and obstetrics, 1990, 31(suppl.):35-41.

29. Al-Sekait M. A study of the factors influencing breast-feeding pattern in Saudi Arabia. Saudi medical journal, 1988, 9:596.

30. El-Sayed HF, Waheeb Y, Mehana S. Breast-feeding among working mothers in Egypt. A systemic review of the literature. San Diego, WellStart International: $1-62$.

31. Simopolous AP, Gave GD. Factors associated with the choice and duration of infant feeding practice. Pediatrics, 1984, 74(suppl.):603--14.

32. El-Masry RSA. Breastfeeding and maternal employment in the University of Mansoura [MSc Thesis in Public Health]. Mansoura, Egypt, Faculty of Medicine, University of Mansoura, 2000.

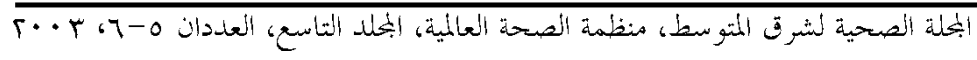

